\title{
$13: 50925135-50837364$
}

National Cancer Institute

\section{Source}

National Cancer Institute. 13:50925135-50837364. NCI Thesaurus. Code C42124.

Physical location of DDX26_Gene 